\title{
Political Commitments and Aspirations of Grassroots Coastal Communities: a Micro-Level Study in Bangladesh
}

\author{
Mohammed Mamun Rashid* \\ Community Development Centre (CODEC) Plot No- 2, Road No-2, Lake Valley R/A Foy's Lake, Chittagong, Bangladesh \\ *Corresponding author: rashidmamuns@yahoo.com
}

Received May 25, 2014; Revised June 19, 2014; Accepted June 19, 2014

\begin{abstract}
This paper attempts to find out perception of disadvantaged coastal communities about their lives and livelihoods. A total of 400 respondents were surveyed in 27 sub-districts by two sets of questionnaire. Coastal zone of Bangladesh comprises distinctive problems and prospects but relatively income-poor in comparison with rest of the country. Findings reveal that this zone offers immense potential for economic growth. This study finds that duration of Coastal Development Strategy (CDS) is ended in 2010; coastal people urge to revitalize a long-term comprehensive plan for coastal zone and mainstreaming with national \& sub-national planning for escalating their well-beings. In concluding this paper, it is suggested to take special attention for coast by political leaders, policy makers, and other actors that will bring a bright and promising future of Bangladesh.
\end{abstract}

Keywords: coastal communities, manifesto, parliamentary election, political parties, well-beings

Cite This Article: Mohammed Mamun Rashid, "Political Commitments and Aspirations of Grassroots Coastal Communities: a Micro-Level Study in Bangladesh.” American Journal of Rural Development, vol. 2, no. 2 (2014): 24-33. doi: 10.12691/ajrd-2-2-2.

\section{Introduction}

Bangladesh has an area of 147,570 square kilometers and a population of about 149,772,364; making it the most densely populated country in the world. It ranked 146th, out of 187 countries, of the UN Human Development Index and has been improving over the last decade (United Nations Development Programme 2013). World Bank (2013) finds that despite population growth, the population of poor households declined by 26 percent in 10 years. The number of extreme poor people also declined from 44 million in 2000 to 34.6 million in 2005, and down to 26 million in 2010 - a massive 41 percent decrease.

Bangladesh has a parliamentary system of government. The Bangladesh Parliament, Jatiyo shangshad as it is known in Bengali, is a unicameral legislature that presently composed of 350 members, 300 directly elected members under a single member constituency system, and 50 reserved seats for women. The parliamentary mandate is for a period of five years. There are a number of literatures available on historical evolution, structure, institutions and roles of Bangladesh Parliament with its problems and prospects. Thus, this paper does not insight on those issues and concerns. However, Table 1 and Table 2 briefly show political system and information about parliamentary elections of Bangladesh. Tenth parliamentary election was held on 05 January 2014 without participation of major political parties. However,
Political parities usually declare their manifestos before election. Election manifesto is a set of promises made by political parties to the people on account of an election.

The coastal zone of Bangladesh covers 19 out of 64 districts and an Exclusive Economic Zone (EEZ). Approximately one-third of total population live in coastal districts where they mostly depend on fishery, agriculture, forest, local transportation, salt production and so on for their lives and livelihoods.

Planning Commission of Bangladesh (2011) cites that,

The Government is very much concerned about regional disparities and is committed to take all necessary steps to reduce disparities. An important factor that may have contributed to the differences in regional poverty indicators is the issue of the "east-west" divide in terms of access to growth centers. This divide is defined in terms of location of the divisions with reference to the three rivers: the Jamuna, the Padma and the Meghna. Three divisions are on the western side of the rivers: Rajshahi, Khulna and Barisal. The other three divisions, Dhaka, Chittagong and Sylhet, are on the eastern side of the rivers. Concerning regional disparities, the divisions of Dhaka, Chittagong and Sylhet seem to do better in terms of both growth and poverty reduction as compared with Rajshahi, Khulna and Barisal.

Twelve districts, out of total 19 coastal districts, are located in lagging divisions. Water Resources Planning Organization of Bangladesh (2006) states that regarding substantial regional differentiation: in 15 out of the 19 coastal districts, the Gross Domestic Product (GDP) per capita is below national or coastal zone averages. 
Table 1. Date, parties and candidates of parliamentary elections

\begin{tabular}{|c|c|c|c|c|}
\hline Date of Election & Parties/Alliances Contested & Candidates Contested & Candidates with Party Affiliation & Independent Candidates \\
\hline 07 March 1973 & 14 & 1,209 & 1,089 & 120 \\
\hline 28 February 1979 & 29 & 2,547 & 2,125 & 442 \\
\hline 07 May 1986 & 28 & 1,980 & 1,527 & 453 \\
\hline 03 March 1988 & 8 & 1,192 & 978 & 214 \\
\hline 27 February 1991 & 75 & 2,787 & 2,363 & 424 \\
\hline 15 February 1996 & 41 & 1,450 & 993 & 457 \\
\hline 12 June 1996 & 81 & 2,574 & 2,293 & 281 \\
\hline 01 October 2001 & 54 & 1,935 & 1,451 & 484 \\
\hline 29 December 2008 & 38 & 1,567 & 1,416 & 151 \\
\hline 05 January 2014 & \multicolumn{4}{|l|}{ * In tenth election: uncontested seats- 153 and contested seats- 147 } \\
\hline
\end{tabular}

Source: Bangladesh Election Commission (BEC) 2013

Table 2. Political system and Parliaments: 1972-2014

\begin{tabular}{|c|c|c|c|c|}
\hline Parliament & Date of First Session & Date of Dissolution & Political System Elected Majority Party & Tenure (Months) \\
\hline \multicolumn{5}{|c|}{$\begin{array}{c}\text { 1972-1974: Parliamentary Democracy } \\
\text { Provisional Constitutional Order } 1972 \\
\text { Bangladesh Constitution } 1972\end{array}$} \\
\hline First & 07 April 1973 & 06 November 1975 & Awami League (AL) & 30 \\
\hline \multicolumn{5}{|c|}{ January 1975: Presidential form of Government, $4^{\text {th }}$ Amendment of the Constitution } \\
\hline \multicolumn{5}{|c|}{ 1975-1981: Military Rule (Presidential form of Government) } \\
\hline Second & 02 April 1979 & 24 March 1982 & Bangladesh Nationalist Party (BNP) & 35 \\
\hline \multicolumn{5}{|c|}{ 1981-1982: Civilian Rule (Presidential form of Government) } \\
\hline \multicolumn{5}{|c|}{ 1982-1990: Military Rule (Presidential form of Government) } \\
\hline Third & 10 July 1986 & 06 December 1987 & Jatiya Party (JP) & 17 \\
\hline Fourth & 25 April 1988 & 06 December 1990 & Jatiya Party (JP) & 31 \\
\hline \multicolumn{5}{|c|}{ 1991: Restoration of Parliamentary Democracy } \\
\hline Fifth & 05 April 1991 & 24 November 1995 & Bangladesh Nationalist Party (BNP) & 56 \\
\hline Sixth & 19 March 1996 & 30 March 1996 & Bangladesh Nationalist Party (BNP) & 12 days \\
\hline Seventh & 14 July 1996 & 13 July 2001 & Awami League (AL) & 60 \\
\hline Eighth & 28 October 2001 & 27 October 2006 & BNP-led Four Party Alliance & 60 \\
\hline \multicolumn{5}{|c|}{ 2007-2008: Military-backed Caretaker Government } \\
\hline Ninth & 25 January 2009 & 24 January 2014 & AL-led Grand Alliance & 60 \\
\hline Tenth & 29 January 2014 & Ongoing & Awami League (AL) & - \\
\hline
\end{tabular}

Source: Centre for Policy Dialogue 2012; Bangladesh Parliament 2014

Bangladesh is already vulnerable to many gradual change phenomena of climate change and climate related extreme events. According to Climate Change Vulnerability Index (CCVI) 2013, released by the UK based global risks advisory firm Maplecroft, "Bangladesh is at extreme risk". The coastal zone of Bangladesh will always be vulnerable for climate change as confirmed by the International Organization for Migration (2010), "Sealevel rise is the most often cited cause of predicted massdisplacement within Bangladesh as a result of climate change. Widely quoted figures range from 13 million to 40 million people displaced, generally based on assumptions of a one metre rise in sea levels”.

Coastal areas of Bangladesh face with several natural hazards like cyclone, storm surge, flood etc. In addition, there have man-made different hazards like arsenic, waterlogging and salinity in water \& agricultural land. Noteworthy, this zone has diverse eco-systems: mangrove, marine, estuary, islands, coral, sandy beaches, sand dunes and has both 'world heritage sites' and 'ecologically critical areas'. Coastal zone offers immense potential for economic growth. Renewable and nonrenewable energy, marine resources, beach minerals tourism are some of the less explored areas.

The Constitution of Bangladesh bestows special provision for development of disadvantaged areas including remote coastal areas. Moreover, a total of 87 Members of Parliament (MPs) were directly elected in ninth parliamentary election from coastal districts. Despite having potentials, socio-economic conditions of coastal communities remain disappointing and, in some extents, improving steadily. Against this background, this paper considers expectations of coastal communities for reflecting in political commitment. Coastal zone of Bangladesh is very wide in range. Its extent of problem and prospect is also very wide. There are many differences among coastal areas. Though it is very difficult to address all problems and issues of entire coast by this small-scale endeavor but will provide an overview how grassroots people perceive their problems \& prospects and raising recommendations for coastal governance and well-beings. An attempt is made to pinpoint some characteristics of lives and livelihoods scenario of coastal areas. Based on primary research done by author, initially this paper intended for pursuing to address demands of grassroots people in tenth parliamentary election manifesto of political parties but did not proceed due to unfavorable political situation. Now eleventh parliamentary election of Bangladesh is in political dialogue and dilemma. Whatsoever, voices of grassroots coastal communities, by this paper, still have significant to be heard by political leaders and carried forward in mainstreaming planning documents.

\section{Methods and Materials}

This research adopts a mixed method, applying both qualitative and quantitative methodologies in collecting, assessing and analysis data. Field work was conducted in 27 upazilas (sub-district) of 11 coastal districts during July-August 2013. Study areas, that is, purposive upazilas (sub-district) of randomly selected districts are Bagerhat Sadar, Kachua, Rampal, Morrelganj, Mongla, Saran Khula (Bagerhat district); Amtali, Taltali, Barguna Sadar, Patharghata, Bamna (Barguna district); Barisal Sadar, 
Bakerganj (Barisal district); Bhola Sadar, Char Fasson, Daulatkhan (Bhola district); Sitakunda (Chittagong district); Pekua (Cox's Bazar district); Dacope, Koyra (Khulna district); Ramgati (Laxmipur district); Patuakhali Sadar, Kalapara, Mirzaganj (Patuakhali district); Mathbaria (Pirojpur district); Assasuni and Shyamnagar (Satkhira district).

Table 3. Age, education and occupation of respondents

\begin{tabular}{|c|c|c|c|c|}
\hline SL & Elements & Particulars & Respondents & Total \\
\hline \multirow{10}{*}{1} & \multirow{10}{*}{ Age } & 15 to 19 years & 3 & \multirow{10}{*}{400} \\
\hline & & 20 to 24 years & 9 & \\
\hline & & 25 to 29 years & 25 & \\
\hline & & 30 to 34 years & 53 & \\
\hline & & 35 to 39 years & 75 & \\
\hline & & 40 to 44 years & 58 & \\
\hline & & 45 to 49 years & 62 & \\
\hline & & 50 to 54 years & 46 & \\
\hline & & 55 to 59 years & 41 & \\
\hline & & 60 years and plus & 28 & \\
\hline \multirow{8}{*}{2} & \multirow{8}{*}{$\begin{array}{l}\text { Educational } \\
\text { qualification }\end{array}$} & Illiterate & 19 & \multirow{8}{*}{400} \\
\hline & & Signature knowledge & 74 & \\
\hline & & Primary school & 88 & \\
\hline & & High school & 47 & \\
\hline & & $\begin{array}{l}\text { Secondary School } \\
\text { Certificate (SSC) }\end{array}$ & 17 & \\
\hline & & $\begin{array}{l}\text { Higher Secondary } \\
\text { Certificate (HSC) }\end{array}$ & 34 & \\
\hline & & Graduate & 53 & \\
\hline & & Post-graduate & 68 & \\
\hline \multirow{16}{*}{3} & \multirow{16}{*}{ Occupation } & Advocate & 13 & \multirow{16}{*}{400} \\
\hline & & Agricultural laborer & 32 & \\
\hline & & Association leader & 8 & \\
\hline & & $\begin{array}{c}\text { Community Based } \\
\text { Organization (CBO) } \\
\text { leader }\end{array}$ & 6 & \\
\hline & & Day laborer & 32 & \\
\hline & & Farmer & 45 & \\
\hline & & Fisherman & 70 & \\
\hline & & Fishing laborer & 35 & \\
\hline & & $\begin{array}{c}\text { Forest dependent } \\
\text { people }\end{array}$ & 28 & \\
\hline & & Journalist & 24 & \\
\hline & & $\begin{array}{c}\text { Medium-scale } \\
\text { business }\end{array}$ & 18 & \\
\hline & & NGO activist & 13 & \\
\hline & & Private service & 18 & \\
\hline & & Small-scale business & 14 & \\
\hline & & Teacher & 39 & \\
\hline & & Village doctor & 5 & \\
\hline
\end{tabular}

A total of 400 respondents were surveyed with questionnaire. Table 3 gives information about age, educational qualification and occupation of respondents. Two sets of questionnaire were developed for data collection. First questionnaire centered on basic demographics, occupational pattern, income, land ownership, livelihood challenges, experience with discrimination and vulnerabilities. It was used for collecting data from agriculture laborer, farmer, day laborer, fisherman, fishing laborer and forest dependent people. Second questionnaire concerted on open-ended questions about climate change, hazards, land use, water \& sanitation, health services, education, youth development, women empowerment and rural employment. This questionnaire was used to obtain data from rest of respondents. All respondents were requested to provide recommendations, as they deem, for inclusion in election manifesto.

Existing secondary sources (books, articles, documents) relevant with parliamentary election, political parties and socio-economic development of coastal communities in
Bangladesh were reviewed for incorporating facts and findings in this paper. Moreover, previous four election manifestos of two big political parties, that is, Awami League (AL) and Bangladesh Nationalist Party (BNP) were considered for identifying given set of commitments related with development of coastal areas.

\subsection{Coastal Zone of Bangladesh}

Bangladesh has a coastline of 710 kilometers and an Exclusive Economic Zone (EEZ). There are different views on the delimitation of the coastal areas. The conventional view is that the land that is inundated by the high and low tides is called the coastal belt. Coastal zones refer to areas where land and sea meet.

Three indicators have been considered for determining the landward boundaries of the coastal zone of Bangladesh. These are: influence of tidal waters, salinity intrusion and cyclones/storm surges. Total 19 districts of the country are being affected directly or indirectly by some of these phenomena. The districts are considered including all upazilas (sub-district)/thanas (police station). A total of 48 upazilas/thanas in 12 districts are exposed to the sea and/or lower estuaries, are defined as the exposed coast and the remaining 99 of the coastal districts are termed interior coast (WARPO 2005). Over the periods, Government of Bangladesh (GoB) realigned jurisdictions and declared some new administrative units. Now 161 upazilas/thanas are comprised in 19 coastal districts (Ministry of Public Administration 2013 \& Bangladesh Police 2013).

Table 4. Area, households and population of coastal districts and Bangladesh

\begin{tabular}{|c|c|c|c|c|c|}
\hline \multirow{2}{*}{ District } & \multirow{2}{*}{$\begin{array}{l}\text { Area } \\
\left(\mathrm{km}^{2}\right)\end{array}$} & \multicolumn{2}{|c|}{ Households } & \multicolumn{2}{|c|}{ Population (Adjusted) } \\
\hline & & 2001 & 2011 & 2001 & 2011 \\
\hline Bagerhat & 3,959 & 323,505 & 354,223 & $1,620,281$ & $1,534,012$ \\
\hline Barguna & 1,831 & 179,968 & 215,842 & 887,678 & 927,890 \\
\hline Barisal & 2,785 & 474,076 & 513,673 & $2,465,632$ & $2,414,730$ \\
\hline Bhola & 3,403 & 328,670 & 372,723 & $1,780,582$ & $1,846,352$ \\
\hline $\begin{array}{c}\text { Chandpu } \\
\text { r }\end{array}$ & 1,704 & 433,768 & 506,521 & $2,377,402$ & $2,513,837$ \\
\hline $\begin{array}{c}\text { Chittago } \\
\text { ng }\end{array}$ & 5,283 & $\begin{array}{c}1,240,53 \\
7\end{array}$ & $\begin{array}{c}1,532,01 \\
4\end{array}$ & $6,966,450$ & 7,913,365 \\
\hline $\begin{array}{l}\text { Cox’s } \\
\text { Bazar }\end{array}$ & 2,492 & 296,109 & 415,954 & $1,854,534$ & $2,381,816$ \\
\hline Feni & 928 & 223,049 & 277,665 & $1,297,789$ & $1,496,138$ \\
\hline $\begin{array}{c}\text { Gopalgo } \\
\text { nj }\end{array}$ & 1,490 & 221,986 & 249,872 & $1,218,698$ & $1,218,319$ \\
\hline Jessore & 2,567 & 524,127 & 656,413 & $2,586,688$ & $2,876,381$ \\
\hline $\begin{array}{c}\text { Jhalokath } \\
\text { i } \\
\end{array}$ & 749 & 144,923 & 158,139 & 726,586 & 709,915 \\
\hline Khulna & 4,394 & 499,324 & 547,347 & $2,508,749$ & $2,407,680$ \\
\hline $\begin{array}{c}\text { Laxmipu } \\
\text { r }\end{array}$ & 1,456 & 288,736 & 365,339 & $1,558,485$ & $1,797,761$ \\
\hline Narail & 990 & 141,071 & 162,607 & 730,616 & 750,424 \\
\hline Noakhali & 3,601 & 460,394 & 593,918 & $2,695,565$ & $3,231,832$ \\
\hline $\begin{array}{c}\text { Patuakha } \\
\text { li }\end{array}$ & 3,221 & 287,101 & 346,462 & $1,527,683$ & $1,596,222$ \\
\hline Pirojpur & 1,308 & 232,962 & 256,002 & $1,161,938$ & $1,157,215$ \\
\hline Satkhira & 3,858 & 390,745 & 469,890 & $1,950,455$ & $2,063,610$ \\
\hline $\begin{array}{c}\text { Shariatpu } \\
\text { r }\end{array}$ & 1,182 & 213,677 & 247,880 & $1,132,600$ & $1,201,464$ \\
\hline $\begin{array}{l}\text { Coastal } \\
\text { Zone }\end{array}$ & $\begin{array}{c}47,20 \\
1\end{array}$ & $\begin{array}{c}6,904,72 \\
8\end{array}$ & $\begin{array}{c}8,242,48 \\
4\end{array}$ & $\begin{array}{c}37,048,41 \\
1\end{array}$ & $\begin{array}{c}40,038,96 \\
3\end{array}$ \\
\hline $\begin{array}{c}\text { Banglade } \\
\text { sh }\end{array}$ & $\begin{array}{c}147,5 \\
70 \\
\end{array}$ & $\begin{array}{c}25,490,8 \\
16 \\
\end{array}$ & $\begin{array}{c}32,173,6 \\
30\end{array}$ & $\begin{array}{c}130,354,0 \\
60 \\
\end{array}$ & $\begin{array}{c}149,772,3 \\
64 \\
\end{array}$ \\
\hline $\begin{array}{c}\text { Percenta } \\
\text { ge }\end{array}$ & 31.99 & 27.09 & 25.62 & 28.42 & 26.73 \\
\hline
\end{tabular}

Source: Bangladesh Population and Housing Census 2011 


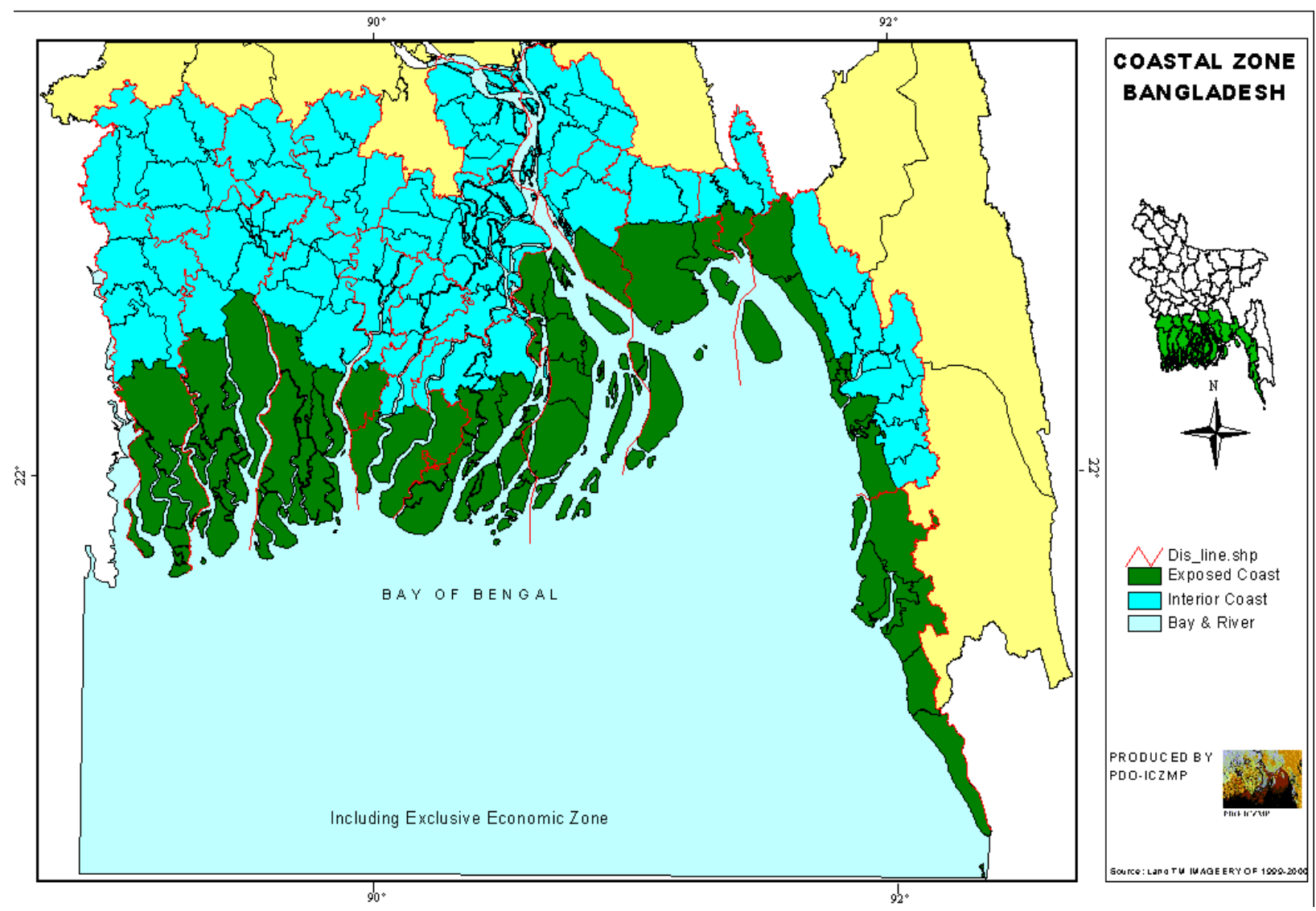

Map 1. Coastal Zone of Bangladesh. Source: Islam et al., 2006.

In exercise of the powers conferred by sub-section (1) of section 5 of the Territorial Waters and Maritime Zones Act, 1974 (Act no. XXVI of 1974), the Government declared the Zone of the high seas extending to 200 nautical miles measured from the baselines shall be the economic zone of Bangladesh. Exclusive Economic Zone (EEZ) has been included in the coastal zone of Bangladesh (PDO-ICZMP 2003; IUCN 2011). Fortunately, on 14 March 2012 Bangladesh won the landmark verdict at the International Tribunal for the Law of the Sea in Hamburg, Germany. The court sustained Bangladesh's claim to rights over a 200-nautical-mile exclusive economic and territorial zone in the Bay of Bengal, thereby rejecting the claims of Myanmar. The verdict cannot be appealed against and has become effective immediately.

Table 4 shows geographical coverage, households and population of coastal districts. It is found that 28.42 percent of total population of Bangladesh lived in coastal districts in 2001. Growth rate of population has been declined due to lack of employment opportunities, livelihood problems and social challenges.

People of coastal areas are still braved and struggling with many odds. Now days the threat of cyclonic storm like Sidr, Aila and tidal wave and cyclone of 1970, 1991, 2007 and 2008 has become a permanent phenomenon in their life. However, it could not be said that initiatives for coastal development is very new as confirmed by Water Resources Planning Organization (WARPO) of Bangladesh. WARPO (2006) validates that attempts to introduce area specific approach in the coastal zone, however, are not new. This was already pursued through a number of earlier initiatives: 1) Off-Shore Islands Development Board (1977-82); 2) Bangladesh National
Conservation Strategy (1987); 3) UN/ESCAP-GoB Coastal Environment Management Plan for Bangladesh (1987); 4) Coastal Area Resources Development Plan (1988); 5) Formation and Activities of the Special Parliamentary Committee on Coastal Area Development (1988-90); and 6) National Capacity Building on ICZM initiative (1997).

IUCN (2011) cites that Bangladesh has accredited a number of International Conventions, Treaties and Protocols (ICTPs) most of them with stakes in coastal development, conservation or protection. However, zonespecific policy and development strategy address issues and concerns of coastal areas. For instance, Coastal Zone Policy (2005) and Coastal Development Strategy (2006) provide framework for integrated coastal zone management. Moreover, aspects of coastal development are embedded in activities/programs/projects of sectoral ministries and agencies. Khan, Khan \& Ullah (2012) states that Coastal Development Strategy (CDS) of Bangladesh recognized specificity and unique conditions of coastal people and their development needs. The duration of Coastal Development Strategy (CDS) was five years starting from 2006, which means duration is over and now there is no other consultative process regarding coastal zone development. There is no separate chapter or section on coastal area in present Sixth Five Year Plan (20112015). This plan emphasizes to tackle special problems of coastal regions such as Barisal Division that face tremendous risks of natural disasters owing to geography. It is not clear whether the Coastal Development Strategy (CDS) projects are incorporated in the Sixth Five Year Plan (SFYP) under the "regional disparity" discourse or the Coastal Development Strategy (CDS) is abandoned. 


\section{Results and Discussion}

\subsection{Commitments in Election Manifestos}

All respondents urge that issues and concerns of coastal areas should be addressed in election manifesto of all political parties with priority. Their logical approaches are: a) it is a constitutional right to obtain priority as majority of them live in disadvantaged communities; b) coastal areas have distinctive problems \& opportunities and demanding mainstreaming development efforts, c) onethird of total population live in coastal belt, and 4) special attention to coast will escalate well-beings of coastal communities and national development. Usually implementation of a commitment under election manifesto brings benefit directly and indirectly for all. However, Table 5 points up some distinctive issues that were written at four election manifestos of following two political parties for coastal development. Praiseworthy, set of commitments in election manifesto of Awami League (AL) and Bangladesh Nationalist Party (BNP) has been increased from 1991 to 2008. Issues of coastal development have gradually been addressed more in election manifesto of both political parties.

Table 5. Distinctive set of commitments for coastal development

\begin{tabular}{|c|c|}
\hline Year & Awami League (AL) \\
\hline 2008 & $\begin{array}{c}\text { To continue distribution of khas lands (government owned lands) } \\
\text { among landless people } \\
\text { To distribute khas water bodies among real fishermen } \\
\text { To take initiative for land reclamation in coastal areas } \\
\text { To protect coastal communities from adverse affects of global } \\
\text { warming; initiatives will be taken for river dredging, sweet water } \\
\text { reserve, preventing riverbank erosion, and protecting bio-diversity } \\
\text { To extend irrigation and preventing water salinity } \\
\text { To dredge rivers and ensure navigation round the year; development } \\
\text { of low-cost and safe waterway transportation } \\
\text { To construct deep-sea ports; modernizing of Chittagong \& Mongla } \\
\text { sea ports and open for Asia } \\
\text { To establish community radio in coastal areas }\end{array}$ \\
\hline 2001 & $\begin{array}{c}\text { To continue and expand Asrayan (poverty alleviation through } \\
\text { rehabilitation and income generation) project for rehabilitation of } \\
\text { riverbank eroded homeless-landless people } \\
\text { To continue distribution of khas lands among landless people } \\
\text { Efforts will be made for leasing of government water bodies for real } \\
\text { fishermen and arranging adequate loans with easy terms } \\
\text { To construct Padma Bridge } \\
\text { Importance will be given for increasing navigation, development of } \\
\text { terminals and safe waterway transportation } \\
\text { Prioritized actions will be taken for ensuring balance development of } \\
\text { lagging areas }\end{array}$ \\
\hline 1996 & $\begin{array}{l}\text { To ensure distribution of khas lands among landless people } \\
\text { Necessary planning and steps will be taken for ensuring equal } \\
\text { development of coastal islands }\end{array}$ \\
\hline 1991 & - \\
\hline
\end{tabular}

\subsection{Lives and Livelihoods}

\subsubsection{Peasants}

Like the other parts of Bangladesh, coastal livelihoods are largely depended on agricultural crops, mainly rice, that is, agriculture predominates. Many problems of farmers in coastal areas and other parts of Bangladesh are similar especially regarding subsidy of agricultural inputs, loans, access to information and marketing. For instance, availability of good quality agricultural inputs like seeds, fertilizers, insecticides etc. is not easy. The price of agricultural inputs is also increasing. Moreover, adulterated fertilizer, insecticides and low quality seeds are widely available and sold in the market, and farmers are cheated in most cases. But farmers of coastal areas have to face additional severe problems like adverse effects of climate change, poor infrastructure and transportation.
Bangladesh Nationalist Party (BNP)

To take necessary measures for development of waterway transportation

To take initiative for establishing deep-sea port

To properly extract resources from sea \& riverine areas and utilize on behalf of national interest

To start mobile medical unit for ensuring health services for people of coastal and char lands

To construct Padma bridge for creating employment in Barisal and

Khulna; establish special economic zone at adjunct areas

To regularly dredging for increasing navigation; taking initiative for development of waterway transportation and safe communication

To develop government water bodies and ensure leasing for real fishermen under specific policy

To provide necessary supports for fishermen to fulfill national demand of fishes and exporting in aboard

To plan for ensuring best economic utilization of accreted char lands and wetlands To extend greenbelt in coastal areas

To regularly dredging and take other programs for preventing riverbank erosion and increasing navigation

To develop waterway transportation by the government and private sector for improving communication of coastal areas especially islands

To develop tourism including in Sundarban by the government and private sector

To ensure leasing of government water bodies for real fishermen under specific policy; facilitating to get bank loans easily. Multiple plans will be taken for socio-economic development of fishermen To encourage coastal aforestation

To minimize damages of natural calamities and protecting lives \& livelihoods by comprehensive disaster management program

To minimize damages of natural calamities by comprehensive disaster management program

To take initiative for preventing riverbank erosion and increasing navigation

To develop tourism including in Sundarban by the government and private sector

The measurement of landless in Bangladesh differs according to the definition found in the statistical sources. Landless households are those households who don't own any type of land (Bangladesh Bureau of Statistics 2008). BBS (2010) also affirms that household that does not own any land in the name of any family member of the household is considered as landless (owned land). Household that does not have any operated land on the day of enumeration is considered as landless (operated). Table 6 shows that 8.89 percent of total farmers are landless. They have neither cultivatable land nor even homestead land. The arable land has been divided into smaller and smaller units, often so small that they cannot support a family. On the other hand, 2.22 percent of total farmers have more than seven and half acre lands. Usually land owners of coastal area live in city or nearby town. However, total 77.78 percent farmers are engaged with sharecropping \& one year leasing system and 68.89 percent farmers cultivate only one crop round the year. 
Absenteeism and negligence of land owners gradually decrease fertility and deteriorate soil health.

Table 6. Status of land ownership among farmers (\%) N = 45

\begin{tabular}{|c|c|c|c|c|c|c|}
\hline \multirow{2}{*}{ Categories } & \multicolumn{7}{|c|}{ Land size (in acre) } \\
\cline { 2 - 7 } & Landless & $\begin{array}{c}0.01- \\
0.49\end{array}$ & $\begin{array}{c}0.50- \\
0.99\end{array}$ & $\begin{array}{c}1.00- \\
2.49\end{array}$ & $\begin{array}{c}2.50- \\
7.49\end{array}$ & $7.50+$ \\
\hline Father & 4.44 & 20.00 & 26.67 & 22.22 & 15.56 & 11.11 \\
\hline Respondent & 8.89 & 44.44 & 22.22 & 15.56 & 6.67 & 2.22 \\
\hline $\begin{array}{c}\text { *Rural } \\
\text { household }\end{array}$ & 4.6 & 60.5 & 11.6 & 14.6 & 7.6 & 1.1 \\
\hline
\end{tabular}

It is significant to note that in some areas sluice gates are dysfunctional, saline water enters inside the polders and damages crops. Saline is creeping into croplands. Increasing salinity creates scarcity of fodder for domestic animals. Perennial water-logging due to inadequate drainage and faulty operation of existing sluice gates restrict potential land use of low lands within the polder areas. Encroachment of river and canal hinders normal water flow and creates water-logging.

Total 82.22 percent farmers are not used to do suitable agricultural system for cultivating salt-tolerant and water stagnant-tolerant varieties. Farmers do not have sufficient training and capacity to cultivate such varieties. Initiative of local agriculture extension department is slim for replicating tested varieties at grassroots level. Weak market access due to remote market places, middlemen, lack of adequate transport facilities, storages and high transport costs are some of the reasons that are responsible for low price of agricultural produces.

\subsubsection{Fisherfolk}

Fishing is largest profession after farming. In the coastal zone of Bangladesh around 0.5 million (family members 2.7 million) household's primary income source is fishing. Over 160,000 fishermen and estimated 185,000 shrimp fry collector are involved in the sector. Traditional fishing communities are being put under pressure by newcomers who take up fishing as their profession. Alam (1996) cites that fishing has become an alternative source of employment, part time or full time, for poor and landless peasants living in the riverine and coastal areas of Bangladesh. Small-scale fishery is seen as a last resort to earn one's livelihood.

It is evident that majority (71 percent) of fishermen and fishing laborers have stiff experienced to be victimized by the pirates several times in their occupational life. Piracy is a big syndicate and managed by ill-treated influential gang. Pirates usually kidnap victims and claim ransoms. However, fishers usually receive loans and social shelter from moneylenders, like Aratdar (wholesaler) / Paiker (middleman who gives advance payment; mostly representative of wholesaler) / Dadandar (advance payment giver), at high interest rates and generally on the condition that the borrower will sell all catches to the moneylenders. It is found that majority (78 percent) of fishermen are entrapped in vicious cycle of Dadan (advance payments as loans). It starts from Taka 10,000 to $1,000,000$ (USD $\$ 125-\$ 12,500$, exchange rate $\$ 1$ USD = 80 Taka). Total 51.28 percent of them receive Taka 50,000 (USD \$625) and above. They are enchained of Dadan from many years, even generations to generations. However, duration of 47.44 percent Dadan recipients is 10 years and up.
Fishers usually have to engage in alternative jobs during Jatka (juvenile hilsha fish) catching banning period, that is, from Kartik (October-November) to Baisakh (April-May). The Government of Bangladesh (GoB) provides 120 kilograms rice to each fishing family during above period. Unfortunately, 58.82 percent of total fishing families receive such support. This support is so little that it has no significant impact. Moreover, the average size of fishing households (6.34) is higher than national average (4.50) referred in Household Income-Expenditure Survey (HIES) 2010. It is significant to note that they were not able to go sea for fishing on average 58 days due to signals of rough weather in last two years; though sometimes compelled only for their survival or to meet the demand of moneylender. Fishermen lose their lives and means of livelihood during devastating disasters. There has lack of strong radio frequency and mobile network in deep sea area. Regrettably, only 19 percent of small-boats have registration from local authority. As a result affected small-boats are not formally counted by the relevant authority. Although fishing is a risky occupation, only 12 percent of fishermen and fishing laborers are under the coverage of life insurance.

\subsubsection{Forest Dependent People}

Forest dependent people, herein, on Sundarban (world largest mangrove forest with rich bio-diversity) for livelihoods are poor. They face different problems in harvesting the resources. Poverty, exploitation and oppression are integral part of their day to day livelihood. The main forest dependent people are bawali (wood feller), mawali (honey and wax collector), and fishers. Respondents inform that resource users have to collect permission letter and pay government fees for entering in Sundarban but officials of Forest Department (FD) take fixed amount of bribe from them which is sometime 10 to 20 times higher than actual fees. Moreover, majority resource users of Sundarban have to pay a fixed amount of money regularly to the dacoits; otherwise they are subjected to abduction and killing. They are also enchained by vicious cycle of Dadandar (moneylender).

\subsubsection{Climate Change}

Temperature, rainfall, wind pattern and solar radiation mainly characterize the climatic systems of Bangladesh and determine the seasons. Islam \& Neelim (2010) classified Bangladesh into four distinct climatic seasons. These are: 1) Pre-monsoon (March to May) with high temperatures with high evaporation rates, 2) Monsoon (June to September) with high intensity of rainfall occurrence, 3) Post-monsoon (October to November), characterized as hot and humid period with decreasing rainfall, and 4) Dry or winter seasons (December to February) portrayed as the coolest, driest and sunniest period of the year. Respondents opine that the environment has been changing over the years. They also affirm that there has been changed in seasonal rainfall pattern. Rainfall is erratic. Temperature has been increased over the years. Interviewees closely identify that livelihood sources of coastal communities particularly agriculture and fisheries are climate sensitive. Cyclone, sea-level rise, salt water intrusion, rising temperatures, changing rainfall patterns and other climatic extremes seriously effect on lives and livelihoods. 


\subsubsection{Hazards}

Bangladesh suffers from various natural hazards of which cyclones and associated storm surges are unique to the coast. All respondents realize that they are living within different man-made and natural hazards. Majority (56 percent) of them distinguish that Government of Bangladesh (GoB) has a set of policies, orders, plans and institutional initiatives that both directly and indirectly address issues of disaster management. There have around 2,895 cyclone shelters in 16 coastal districts and construction of new shelters is ongoing process. However, respondents demand to increase standard cyclone shelters according to density of people in risk-prone areas. In many cases environment of cyclone shelter is not congenial for children, adolescent girls, women, disable and elderly people. People suggest for proactively arranging rescue equipments in coastal belt and smoothly implement undertaken planned activities to protect lives and livelihoods of coastal communities.

\subsubsection{Land Use}

Land use patterns of coastal areas are complex and linked with heterogeneous factors. Ahmed (2011) reveals that the land of coastal areas is used in different purposes like agriculture, shrimp farming, salt production, forestry, ship-breaking yards, ports, industry, settlements, wetlands etc. Respondents notify that National Land Use Policy 2001 is not currently convergent to prevent land degradation and ensure its best utilization. Increasing demands for land severely reduce availability of land for agriculture. Sharecroppers and wage laborers lose their livelihoods because of converting agricultural lands into shrimp farms. Land erosion, increasing salinity and waterlogging, uses of adulterated fertilizers, unproductive fallow lands, harassment during land records, conflicting among occupational groups, unplanned urbanization and lack of adequate adapting with appropriate cropping pattern are major concerns. However, distribution process of khas lands (government owned lands) is always in question marks from the wider populations' point of view. Tyrants, mostly rich and ill-treated people under political signboard, illegally grabbed char lands (i.e. land created by river sediment) and khas lands. Marginalized people typically cannot access without paying money or using some sort of benediction from powerful people.

\subsubsection{Water and Sanitation}

The presence of excessive salt in drinking water in the southwestern coastal districts is posing multiple health risks. Salinity has been increased in surface \& ground water and geographically expanding. Ensuring fresh and safe water is a challenge in salinity-prone areas. For example, it is found that majority households of Rampal and Mongla upazilas (sub-district) have to pay on average Taka 800 (USD \$10) monthly for drinking water and prevailing such financial overburden to poor families. Initiatives for harvesting rainwater are still low and some of existing schemes are dysfunctional due to weak management. There is also an acute crisis of availability of safe drinking water at char lands. Most of households use unsafe water from river or canal for cooking, bathing, cleaning, and other household activities. Respondents recognize that use of sanitary latrine is in improving trend. But it is a problem for floating people, displacees, and hardcore poor households for constructing sanitary latrine. Overall, sanitation coverage of coastal communities is always under risk due to natural calamities.

\subsubsection{Health Services}

Respondents point out that though Bangladesh is on track for reducing child mortality and improving maternal health according to MDG targets but condition of remote coastal pockets is disappointing. Retention of qualified doctor in remote char lands and islands has always been a big challenge. Health of coastal communities is severely deplorable due to prevailing of poverty along with lacking of nutrition escalates health hazards and vulnerability. Environmental catastrophe such as existing and prevailing of arsenic with tube-well water, pollution, unhygienic latrine, changes of climate, increasing water salinity, water-logging and so on are some of causes to accelerate water borne diseases and other health hazards.

Post vacancy, insufficient medicines and equipments, low budget allocation, overcrowding of patients in health centers, shyness of female patients to male doctors for explaining in details, lack of gender-friendly environment especially in queue management at outdoor service and unhygienic toilet, lack of intensive monitoring, statistical weakness, mushrooming of unregulated private clinic, private practice by doctor at high fees and cheated by brokers are major problems identified by interviewees. There have lack of awareness about reproductive health and maintenance of hygiene during menstruation, untrained and traditional birth attendants, and scarcity of river-ambulance in char lands and islands.

\subsubsection{Education}

Respondents perceive that lack of quality education is a serious issue in coastal areas. Education quality between rural and urban is alarming. Access to higher education from coastal villages has gradually been decreased. Majority of students cannot usually compete due to lack of sufficient knowledge especially in English, Mathematics and General Knowledge.

Poverty and engaging in child labor making earns for family increase dropout. Overall, lack of awareness on the necessity of formal education, religious beliefs, early marriages, social insecurity, far away school location, shortage of vehicles and not gender-friendly, lack of cocurriculum activities and forced displacement are contributing factors of increasing high school dropout rate. A bulk number of children especially in char lands are deprived from formal education during fishing season. Lack of monitoring in char lands and hard to reach coastal areas, politically patronized weak management committee, lack of qualified teacher, private coaching by teacher at high fees, lack of separate toilet for female students, poor communication, lack of qualified instructor and materials for laboratory and vocational classes are some major issues hampering education. Human capital transformation from coastal communities will be threatened if it prolongs through such process.

\subsubsection{Youth Development and Women Empowerment}

Youths are vital human capital of coastal communities. A large number of coastal youths are dropped out from 
formal education and being unemployed or disguised unemployed. Formal education is also not giving employment guarantee due to lack of quality education and various unavoidable circumstances. Lack of vocational training and job placement, limited access to Information and Communication Technology (ICT), lack of productive usages of ICT materials, ill-treated politicization of youth clubs, inadequate sports and recreational facilities and insufficient value-based learning obstruct youth development. Interviewees emphasize to encourage innovative idea of youths and empowering them with skills and knowledge for productive employment in future.

Women in coastal area are vulnerable in terms of social, economic, political condition and position. In many cases they are socially confined to freedom of mobility, access to higher education, decision-making and enchained under various superstitious systems. They have very little participation in local and state political power structure. Thus, their participation is less in leadership and planning process. Customary practice of dowry, early marriage \& polygamy escalates the domestic women violence. Economic hardship of women is exacerbated due to lack of control over Income Generating Activities (IGAs) and social insecurity. Health of coastal women is seriously affected by adverse effects of climate change.

\subsubsection{Rural Employment}

Interviewees specify that majority parts of distant coastal areas are neglected where hardly any industrial development takes place. Small \& Medium Enterprises (SMEs) do not expand significantly in coastal areas. Investors have less attention due to scarcity of electricity, gas, poor communication and lack of patronization. Comprehensive initiative for industrialization based on coastal resources is still less explored. Coastal agriculture faces many internal and external barriers ranging from policy implication to environmental changes. Agriculture sector has inability to absorb surplus labour force which needs a special recognition to facilitate its development. Now migration from coastal villages has been increased with diversification and complexity.

\subsection{Priority Areas and Recommendations Proposed by Respondents}

Respondents give multiple recommendations. A total of 68 recommendations come up with 2,633 repetitions. Table 7 elucidates priority areas and recommendations.

Table 7. Priority areas and recommendations

Priority areas and recommendations

\begin{tabular}{|c|c|c|c|}
\hline SL & Priority areas and recommendations & Frequency & Rank \\
\hline 1 & $\begin{array}{l}\text { To protect fishermen from pirates; conducting joint operation by Coast Guard, Forest Guard, Navy, Police and RAB. } \\
\text { Strengthening Coast Guard and increase their regular patrolling at night as piracy occurs more during that time }\end{array}$ & 113 & 1 \\
\hline 2 & $\begin{array}{c}\text { Effective measures should be taken to establish industries in town located beside coastal areas; special emphasis should be } \\
\text { given on local resources and environment-friendly consideration }\end{array}$ & 96 & 2 \\
\hline 3 & $\begin{array}{c}\text { To repair old embankment with increasing height and width; and construct new embankment after considering feasibility } \\
\text { and necessity }\end{array}$ & 93 & 3 \\
\hline 4 & $\begin{array}{c}\text { To prepare a long-term (minimum } 25 \text { years) comprehensive plan for development of coastal areas and mainstreaming with } \\
\text { national \& sub-national planning documents }\end{array}$ & 91 & 4 \\
\hline 5 & $\begin{array}{c}\text { Number of standard cyclone shelters should be increased according to density of people in risk-prone areas. These shelters } \\
\text { should be utilized for multipurpose }\end{array}$ & 90 & 5 \\
\hline 6 & To construct Padma Bridge & 82 & 6 \\
\hline 7 & $\begin{array}{l}\text { Special attention; like fulfilling vacant post, monitoring, sufficient medicines \& equipments, maternal, newborn and child } \\
\text { health, midwife, river-ambulance and other facilities should be given in char lands and hard to reach coastal areas; special } \\
\text { emphasis should be drawn for birth control in those areas }\end{array}$ & 80 & 7 \\
\hline 8 & Special budgetary allocation should be made for coastal areas & 69 & 8 \\
\hline 9 & Particular initiative should be taken for ensuring quality education in coastal belt & 69 & 8 \\
\hline 10 & $\begin{array}{c}\text { To give more emphasis on eco-tourism in Cox's Bazar, Kuakata and Sundarban; exploring potentials of new sites in } \\
\text { coastal areas }\end{array}$ & 67 & 9 \\
\hline 11 & $\begin{array}{c}\text { To facilitate loan schemes for fishermen with low interest and soft conditions; efforts should be made for easy insurance of } \\
\text { fishermen and fishing boat, trawler \& gears }\end{array}$ & 65 & 10 \\
\hline 12 & $\begin{array}{c}\text { To take effective measures to protect fishermen, farmer, bawali (wood feller), mawali (honey and wax collector), fry } \\
\text { collector, dry fish processor, salt producer and other marginalized occupational groups from vicious cycle of Dadandar } \\
\text { (moneylender) }\end{array}$ & 65 & 10 \\
\hline 13 & $\begin{array}{c}\text { To improve road communication in coastal areas especially connectivity with growth centers; emphasis should be given for } \\
\text { ensuring development of islands and regular ferry services }\end{array}$ & 61 & 11 \\
\hline 14 & To address problems and prospects of coastal areas with prioritization in next National Five Year Plan (2016-2020) & 58 & 12 \\
\hline 15 & To take initiative for establishing 'Coastal Development Board’ or similar body for strong coordination & 57 & 13 \\
\hline 16 & To ensure safe drinking water especially in salinity-prone areas; reserving of rainwater should be promoted & 56 & 14 \\
\hline 17 & $\begin{array}{l}\text { Alternative employment opportunities should be created during jatka (juvenile hilsha fish) catching banning period. } \\
\text { Rehabilitation of fishermen should be ensured rather than providing little bit cash and kind support }\end{array}$ & 55 & 15 \\
\hline 18 & To promote incentive packages for retention of qualified doctor in hard to reach coastal areas & 55 & 15 \\
\hline 19 & $\begin{array}{c}\text { To emphasize on intensive field research for identifying future patterns of coastal agriculture due to climate change and } \\
\text { replicating research findings at grassroots level }\end{array}$ & 53 & 16 \\
\hline 20 & $\begin{array}{c}\text { National Fisheries Policy } 1998 \text { and law/act should amended for well-beings of marginalized fishermen and sustainable } \\
\text { fisheries management }\end{array}$ & 51 & 17 \\
\hline 21 & To construct gas transmission line to resourceful and potential coastal areas & 49 & 18 \\
\hline 22 & To extend services of Agriculture Department for water-logging and salinity tolerant cropping in coastal areas & 48 & 19 \\
\hline 23 & Attention should be given to establish governance and enabling institutional environment in coastal belt & 48 & 19 \\
\hline 24 & $\begin{array}{c}\text { Special attention should be given to ensure required loans timely for marginalized farmer with low interest and easy } \\
\text { process }\end{array}$ & 45 & 20 \\
\hline 25 & $\begin{array}{c}\text { To accelerate undertaken venture of solar energy and exploit possible potentials of other renewable energy sources; } \\
\text { gradually increase supply of electricity in remote coastal villages }\end{array}$ & 43 & 21 \\
\hline 26 & $\begin{array}{c}\text { To arrange vocational \& technical training and foreign language course for youths; and linkage for job placement at home } \\
\text { and abroad }\end{array}$ & 42 & 22 \\
\hline 27 & Supportive initiative should be taken for sustainable employment and empowerment of coastal women & 41 & 23 \\
\hline
\end{tabular}




\begin{tabular}{|c|c|c|c|}
\hline 28 & $\begin{array}{c}\text { To run shrimp farming in planned way under regulation of land zoning; and emphasize on quality control \& environmental } \\
\text { responsiveness }\end{array}$ & 38 & 24 \\
\hline 29 & $\begin{array}{c}\text { To repair dysfunctional sluice gates and select sites for new sluice gates by considering requirement of the local people; } \\
\text { strengthening local initiatives in management process }\end{array}$ & 37 & 25 \\
\hline 30 & To ensure registration of small-boat and trawler from local authority for safety and welfare supports & 37 & 25 \\
\hline 31 & $\begin{array}{c}\text { To establish sufficient navigation lights at respective channel \& outpost and ensure Global Positioning System (GPS) } \\
\text { device for fishermen; strengthening mobile networks in coastal areas }\end{array}$ & 35 & 26 \\
\hline 32 & $\begin{array}{c}\text { To evict encroachment and illegal structures on canals, rivers \& water bodies and regular excavation for normal water } \\
\text { flow; conservation of fresh water }\end{array}$ & 35 & 26 \\
\hline 33 & $\begin{array}{c}\text { To strengthen Disaster Management Committee (DMC) at District, Upazila and Union levels; increase training, simulation } \\
\text { and equipments for volunteers of Cyclone Preparedness Program (CPP) }\end{array}$ & 35 & 26 \\
\hline 34 & To take special interventions at coastal pockets, prioritized as poverty map, for improving nutrition of mother and children & 34 & 27 \\
\hline 35 & To encourage private investment and Public-Private Partnership (PPP) in coastal areas & 33 & 28 \\
\hline 36 & To enlarge coastal aforestation and continuously emphasize for establishing greenbelt on a priority basis & 32 & 29 \\
\hline 37 & $\begin{array}{c}\text { To provide financial and technical support to hardcore poor households for constructing hazard-resistant sanitary latrine in } \\
\text { coastal areas }\end{array}$ & 32 & 29 \\
\hline 38 & $\begin{array}{c}\text { To take necessary initiative to protect youth generations from drug addiction; arrange more sports \& recreational facilities } \\
\text { and emphasize on value-based education }\end{array}$ & 32 & 29 \\
\hline 39 & $\begin{array}{l}\text { To properly find out inventory of natural resources in Exclusive Economic Zone (EEZ) and ensure its sustainable } \\
\text { utilization. Coastal resources should be explored in sustainable way for economic growth and national interest }\end{array}$ & 29 & 30 \\
\hline 40 & To take appropriate measures for protecting ecosystems and biodiversity of coastal areas & 29 & 30 \\
\hline 41 & Initiatives should be taken to send more migrant workers to international markets from coastal areas & 28 & 31 \\
\hline 42 & Attention should be given for modernization of sea ports and air ports in coastal areas; establishing deep-sea port & 27 & 32 \\
\hline 43 & $\begin{array}{l}\text { To modernize and revive fish preserving and processing units under Bangladesh Fisheries Development Corporation } \\
\text { (BFDC); strengthening existing local sub-stations of fisheries research }\end{array}$ & 26 & 33 \\
\hline 44 & $\begin{array}{c}\text { Special focus \& mainstreaming initiatives should be ensured for development of physically and mentally challenged } \\
\text { people of Bangladesh including coastal areas }\end{array}$ & 25 & 34 \\
\hline 45 & To continue and development of low-cost waterway transportation in and around coastal areas & 23 & 35 \\
\hline 46 & Initiatives should be taken for construction of cyclone-resistant low cost houses in coastal areas & 22 & 36 \\
\hline 47 & To properly utilize allocation of National Climate Change Fund in coastal areas on a priority basis & 22 & 36 \\
\hline 48 & To establish mobile school and clinic in remote char land especially during fishing season & 22 & 36 \\
\hline 49 & To expedite benefits of Union Information Service Centers in remote coastal areas & 21 & 37 \\
\hline 50 & To provide allowance for government employees who are posted in hard to reach coastal areas & 21 & 37 \\
\hline 51 & $\begin{array}{l}\text { To take effective measures for expansion of Small and Medium Enterprises (SMEs) activities and liking with financial \& } \\
\text { advisory institutions }\end{array}$ & 20 & 38 \\
\hline 52 & $\begin{array}{l}\text { Bangladesh Climate Change Strategy and Action Plan (2009-2018) should be implemented through proper consultation } \\
\text { with coastal people and respective stakeholders; needful modification of this plan should be done through participatory } \\
\text { way }\end{array}$ & 20 & 38 \\
\hline 53 & $\begin{array}{c}\text { To ensure access of marginalized people especially women to khas lands (government owned lands), water bodies and } \\
\text { other public commons }\end{array}$ & 19 & 39 \\
\hline 54 & $\begin{array}{l}\text { To take necessary initiative to prevent riverbank erosion and rehabilitation of riverbank eroded people; national policy } \\
\text { should be adopted to protect Internally Displaced Persons (IDPs) }\end{array}$ & 18 & 40 \\
\hline 55 & To proactively arrange necessary equipments and coastal-favorite logistic supports for rescue of disaster victims & 15 & 41 \\
\hline 56 & $\begin{array}{c}\text { To save coastal area from pollution like polluting by residues of ship-breaking, ship-building, agro \& industrial chemicals, } \\
\text { garbage, waste disposal from vessels, trash fish and other sources }\end{array}$ & 15 & 41 \\
\hline 57 & Special focus should be given for livelihood security of traditional fisherfolk & 14 & 42 \\
\hline 58 & $\begin{array}{c}\text { To take diplomatic initiative for releasing detained fishermen from jail of neighboring countries; proper treatment and } \\
\text { reintegration of returnees should be ensured }\end{array}$ & 14 & 42 \\
\hline 59 & Patrolling should be increased to stop illegal entrance of foreign fishing vessels & 12 & 43 \\
\hline 60 & Community radio station should be established in coastal areas & 10 & 44 \\
\hline 61 & To prohibit factory of illegal net (current net) production & 10 & 44 \\
\hline 62 & To protect and promote heritage \& cultural of coastal communities including indigenous people & 9 & 45 \\
\hline 63 & $\begin{array}{l}\text { To strengthen and revise Terms of Reference (TOR) of supervisory agencies at grassroots for ensuring pro-poor and } \\
\text { environment-friendly benefits from private investment and Public-Private Partnership (PPP) }\end{array}$ & 9 & 45 \\
\hline 64 & To ensure sufficient equipments and logistic supports for law enforcing agencies deployed in remote coastal areas & 8 & 46 \\
\hline 65 & To take initiative to solve land-related disputes and cases in coastal areas & 7 & 47 \\
\hline 66 & To rehabilitate widows whose husbands were killed by tiger; and arrange high-quality medical support locally for victims & 6 & 48 \\
\hline 67 & Necessary initiative should be taken to prohibit fish catching by using pesticide particularly nearby Sundarban & 5 & 49 \\
\hline 68 & To encourage Corporate Social Responsibility (CSR) for human development of coastal communities & 5 & 49 \\
\hline
\end{tabular}

\section{Conclusion}

This field based study finds that coastal zone is relatively income-poor in comparison with rest of the country. Some districts and sub-districts are located at poverty pocket that were identified by the Government of Bangladesh (GoB). This paper urges to take holistic initiatives for coastal development rather than scattered courses of action. A long-term comprehensive plan should be undertaken with adopting \& revitalizing strategic directions and mainstreaming with national \& subnational planning documents. Despite a number of aspirations already articulated in previous plans or implementations, but exiting demands of grassroots people accumulated by this study will help respective stakes to review undertaking interventions and setting future initiatives. Finally, this paper is advocating, on behalf of coastal communities, with all political parties to address their issues and concerns with priority in election manifesto for a bright and promising future.

\section{Acknowledgement and Limitation}

The author thanks CODEC management and expressed profound gratitude to Dr. Khursid Alam, Executive Director, for his inspiration and support. Sincere appreciation goes to colleagues of PRODIP project for 
helping during field work. The author is also indebted to members of civil society and professional groups who sacrificed their valuable time by providing data and constructive thoughts. The main drawback of this paper is the relatively small sample size which someway limits the generalizability of findings. Side by side, previous election manifestos of only two political parties have been analyzed due to shortage of time. However, the author sincerely believes that the outcomes of this research will be beneficial for political parties, policy makers and other actors.

\section{References}

[1] Ahmed, A., 2011, 'Some of the major environmental problems relating to land use changes in the coastal areas of Bangladesh: A review', Journal of Geography and Regional Planning, Vol. 4 (1), $\begin{array}{llll}\text { viewed } 20 & \text { August } & \text { 2013, from }\end{array}$ http://www.academicjournals.org/jgrp/pdf/pdf2011/Jan/Ahmed.pd $\mathrm{f}$

[2] Alam, K., 1996, 'Two fishing villages of Bangladesh: a community study', PhD thesis, Department of Development and Planning, Aalborg University, Fibigerstraede 2, DK- 9220, Aalborg, Denmark.

[3] Bangladesh Bureau of Statistics 2008, Preliminary Report of Agriculture Census 2008, Bangladesh Bureau of Statistics (BBS), Government of the People's Republic of Bangladesh.

[4] Bangladesh Bureau of Statistics 2010, Household IncomeExpenditure Survey 2010, Bangladesh Bureau of Statistics (BBS), Government of the People's Republic of Bangladesh.

[5] Bangladesh Bureau of Statistics 2011, Population and Housing Census 2011, Statistics and Informatics Division, Ministry of Planning, Government of the People's Republic of Bangladesh.

[6] Bangladesh Election Commission 2013, Parliamentary Elections, viewed 23 August 2013, from http://www.ecs.gov.bd/English/MenuTemplate1.php?Parameter_ MenuID=19\&ByDate $=0$ \&Year $=$

[7] Bangladesh Parliament 2014, Tenure of All Parliaments, viewed 11 March 2014, from http://www.parliament.gov.bd/index.php/en/aboutparliament/tenure-of-parliament

[8] Bangladesh Police 2013, Metropolitan Police, viewed 10 September 2013, from http://www.police.gov.bd/content.php?id=282
[9] Centre for Policy Dialogue, 2012, The Parliament of Bangladesh: Representation and Accountability, Centre for Policy Dialogue (CPD), House- 40/C, Road- 32, Dhanmondi R/A, Dhaka- 1209, Bangladesh.

[10] International Organization for Migration, 2010, Assessing the evidence: Environment, climate change and migration in Bangladesh, Regional Office for South Asia, Dhaka 1212, Bangladesh.

[11] International Union for Conservation of Nature (IUCN), 2011, Sustainable Coastal Zone Management of Bangladesh: A scoping report for Mangroves for the Future, IUCN Bangladesh country office, House- 16, Road- 2/3, Banani, Dhaka- 1213, Bangladesh.

[12] Islam, T. \& Neelim, A., 2010, CLIMATE CHANGE IN BANGLADESH, A CLOSER LOOK INTO TEMPERATURE AND RAINFALL DATA, The University Press Limited, Bangladesh.

[13] Khan, A.R., Khan, Y. \& Ullah, M.S., 2012, Life and Livelihood Conditions of the Coastal Communities and Policies, Community Development Centre (CODEC), Chittagong, Bangladesh.

[14] maplecroft.com, 2013, Climate Change Vulnerability Index 2013, viewed 26 August 2013, from

http://maplecroft.com/portfolio/mapping/maplecroft/?initial_map_ slug=cc_climate_change_vulnerability_2013

[15] Ministry of Public Administration 2013, List of Upazila Nirbahi Officers, viewed 10 September 2013, from

http://www.mopa.gov.bd/index.php?option=com_content\&task=vi ew\&id=432\&Itemid $=486$

[16] Planning Commission of Bangladesh 2011, Sixth Five Year Plan, FY2011-FY2015, Accelerating Growth and Reducing Poverty, Ministry of Planning, Government of the People's Republic of Bangladesh.

[17] Program Development Office for Integrated Coastal Zone Management Plan (PDO-ICZMP) 2003, Delineation of the Coastal Zone, Water Resources Planning Organization (WARPO), Ministry of Water Resources, Government of the People's Republic of Bangladesh.

[18] United Nations Development Programme, 2013, The Rise of the South: Human Progress in a Diverse World, Human Development Report, UNDP.

[19] Water Resources Planning Organization 2005, Coastal Zone Policy 2005, Water Resources Planning Organization (WARPO), Ministry of Water Resources, Government of the People's Republic of Bangladesh.

[20] Water Resources Planning Organization 2006, Coastal Development Strategy 2006, Water Resources Planning Organization (WARPO), Ministry of Water Resources, Government of the People's Republic of Bangladesh.

[21] World Bank, 2013, Bangladesh Poverty Assessment: Assessing a Decade of Progress in Reducing Poverty, 2000-2010, The World Bank Office, Dhaka, Bangladesh. 